IHiS (Indonesian Historical Studies) 4 (2), 155-169 @ 2020 | E-ISSN: 2579-4213

\title{
The Influence of Charismatic Church Development in the Religious Christians Life in Semarang, 1970-2015
}

\author{
Oni Andhi Asmara*, Endang Susilowati, Agustinus Supriyono \\ Master Program of History, Faculty of Humanities, Universitas Diponegoro, \\ Semarang, Indonesia \\ *Corresponding Author: aoniandhi@gmail.com \\ DOI: https://doi.org/10.14710/ihis.v4i2.8253
}

\begin{abstract}
This article discusses the development of the Charismatic church on the Christians life in Semarang City in 1970-2015 using historical methods and using social religion approach. Since its inception in 1970, the Charismatic church in the city of Semarang has had a major influence on the Christian life in the city. A series of innovations in worship and evangelism that are adapted to the times have made

Received:

November 27, 2020 the Charismatic church much in demand by Christians in big cities, one of them is

Revised:

December 2, 2020

Semarang. Christian interest in the Charismatic church can be seen from the development of the number of Charismatic churches in the city of Semarang. One of the Charismatic churches that is experiencing rapid development is JKI Injil Kerajaan. In the beginning, there were 25 people in the congregations. One decade

Accepted:

December 7, 2020 later it reached 3,557 people and continued to increase to 13,324 people on the next decade. This rapid development has brought significant changes to the Christians life in the city of Semarang. It can be seen, among others, from the increasing number of churches that are full of Charismatic churches at worship services. But on the other hand, the presence of Charismatic church with a new pattern of worship caused less harmonious relationship between non-Charismatic churches and charismatic churches as the result of the high increasing number of original church people who moved to the Charismatic church. It is because Christians in Semarang are mostly more interested in taking worship in the Charismatic church.
\end{abstract}

Keywords: Christian Community; Charismatic Church; Worship Innovation; Social Religion.

\section{Introduction}

Indonesia is a diverse country which has a variety of differences, one of it is the difference in religion. Based on Presidential Decree Number 6 Year 2000, there are six recognized official religion, namely Islam, Christian Protestantism, Catholicism, Hinduism, Buddhism, and Confucians. Protestant Christianity is the religion which the largest population after Islam in Indonesia. By 2010, Christian Protestants accounted for 16.5 million people which means $7 \%$ of the total population in Indonesia as reported by Statistics Centre Republic of Indonesia (2010). As one of the large number of adherents throughout the world, the development of Christian Protestant in Indonesia also has broad dynamics. The problem that often arises is the number of denominations or sect. Since the enactment of Law Number 8 of 1985, every religious 
organization must register itself as an association, foundation or organization to the government of the Republic of Indonesia. In 1990, there were 275 Christian Protestant church organizations and more than 400 ecclesiastical foundation or organization so that the overall issue is more than 700 Christian organizations that grow and develop in society (Aritonang, 2003, p. 1).

The people in Semarang represents as multi-ethnic and they live harmoniously, side by side. Diverse religious life in Semarang are relatively calm and almost there is no religious friction which is reflected number of churches in the Semarang. It was recorded by BPS Semarang (2010) that in 2009 there were 279 churches and in 2014 it had risen to 289 churches in Semarang. However, the development of the number of progressive churches certainly increased the complexity of dynamic religious life in Christianity in the City of Semarang (Tim GBI Gajah Mada, 2014).

At the beginning of 1980 emerged a denominational church which had a very rapid development and experienced a very impressive community growth in Indonesia, it was Charismatic church. Since the enforcement of the Law Number 8 Year 1985 about community organization, charismatic church has grown rapidly in the city. The law requires every religious association in Indonesia to register to the Department of Religion. For this reason, Charismatic prayer groups massively enlist themselves as legal religious institutions

The geographical location of Semarang which is the main gate of Central Java province and the strong pluralism of society in the Semarang are making Semarang as one of the capitals cities which the biggest development of Charismatic in Java. The roots of the Charismatic movement in the Semarang are the Pentecostal churches, so that the development of the Charismatic Church in Semarang cannot be separated from the development of the Pentecostal Church. Charismatic term came from Charisma in Greek which means spirit bounty. Spirit bounty relates to Roh Kudus roles in Christian life. The forms of the bounty are such as prophesying, miracles, and uttering spirit language or glossolalia (Aritonang, 2003, p. 197).

One of the Charismatic Churches in Semarang is the Church of the Royal Gospel (JKI), established by Peter Agung Purnomo. When it had just established, the church had a total of 25 people. The church continuously developed until in 2013 increased to 13.324 people (JKI Sinode, 2013). JKI Injil Kerajaan has the biggest church building in Central Java with more or less 27-acre width which is named Holy Stadium and could accommodated 12.000 congregations.

The rapid development of the Charismatic Church in the city of Semarang has made the Charismatic Church often seen obliquely by non-Charismatic churches, even labeled "sheep stealer churches". Since the emergence of the Charismatic movement in 1970 through the parachurch organization until it became a church-based religious organization from the 1980s, the Charismatic churches experienced rapid development. ${ }^{1}$ The process of the Charismatic church enlargement and having strong

${ }^{1}$ Parachurch is a Christian religious fellowship group that is open and not affiliated with a particular church denomination, in fact this parachurch group usually comes from various denominations. 
social services is a phenomenon. Social services such as free schools, public kitchens that distribute food every day, and cheap market events in collaboration with the city government raises the pros and cons in the community. The progressive evangelical movement and the following pros and cons will be interesting to study.

The fundamental difference between the Charismatic church and the nonCharismatic church is in the pattern of worship and the pattern of evangelism. The process of worshiping the Charismatic church takes place more expressively, both in the process of praise and intercession (Kooij \& Tsalatsa, 2007, p. 33). Charismatic church followers will sing praises with full of expression, if the song sung contains a song of victory, the Charismatic congregation will scream and even jump up and down, but if the song sung contains confession, the Charismatic congregation will cry uncontrollably according to the feelings felt by each individual. This certainly contradicts the pattern of non-Charismatic church worship which emphasizes respect for God, so that the atmosphere of worship is more quiet and solemn in accordance with the order of the standard guidelines of worship of each church. The nonCharismatic Church has a liturgy, the liturgy is an absolute ritual of worship and has been preserved since the church's inception. Unlike the non-Charismatic churches, the Charismatic churches do not have a standard liturgy, worship flows according to the spiritual conditions of the congregation and the pastor when the service takes place.

There have been many studies examining the problems of the Charismatic church, but in general it is a theological study with the scope of religious science. Several studies discussing the Charismatic Church including Sutanto's dissertation (1986) to uncover the history of the development of JKI, which is one of the largest Charismatic church synods in Indonesia. Furthermore, study from Basri (2016) examines how the development of the JKI mission strategy of the Injil Kerajaan when Petrus Agung was alive, in growing congregations up to more than 13,000 congregations in 15 years. Meanwhile, Rodemeier (2017) give contribution in contextual background of the rapid development of Pentecostal and Charismatic churches in Java by analyzing the cultural structure of the Javanese people. In addition, Wiraatmaja (2015) analyses on how the growth of the JKI synod based on the quantity of congregations and its branch churches, the data contained in this thesis is very helpful in the research process of this article to reveal the development of the JKI synod over time.

There have been many studies examining the problems of Charismatic churches, but in general it is a theological study within the scope of religious knowledge. This article intended to uncover the development of Charismatic churches and its influences on the Christians religious life in Semarang through a social religious approach by using historical research methods.

\section{Method}

This research article was compiled based on the principle of historical research, namely the process of examining and analyzing records and relics of the past (Gottschalk, 1983, 
p. 32), using a method that includes four steps, namely heuristics (collecting historical sources), criticism, analysis or synthesis, and historiography (writing historical works) (Notosusanto, 1984, 22-24).

The sources used in this study came from several archival institutions and libraries such as the National Archives of the Republic of Indonesia (ANRI), Central Java Provincial Central Archives, Semarang Regional Central Archives, National Unity and Politics of Semarang City Office, Semarang City Christian Community Development Office, Semarang City Church Deliberation Office, STT Abdiel Library, Satya Wacana Christian University Library, STT Sangkakala, and Suara Merdeka Archives Depot. The collection of resources was also carried out in churches that are subjected to the study of historical events that are being studied.

The oral history was conducted by interviewing some competent people who were living witnesses of the development process of the Charismatic church in Semarang. The results of this interview are used as a complement as well as a comparison to the written source (Gottschalk, 1983, p. 35). The data was then verified, analyzed and synthesized so as to produce scientific work with objective analysis.

\section{The Emergence of the Charismatic Church in Semarang}

The Charismatic Movement in Semarang began with the emergence of a small prayer meeting of young Christians. This prayer group developed rapidly from 1970 to 1980 . The prayer groups which had a rapid development, were the Immanuel prayer group and the Sangkakala Family prayer group. The Immanuel prayer group is much in demand by adult congregants, actively carries out prayer services to visit and pray for the sick in various hospitals in Semarang, while the Sangkakala Family prayer group is much in demand by young people because of its active activity in providing services to various schools and colleges in Semarang.

The Immanuel prayer group was founded by Lukas Sebadja and Hana Sebadja while the Sangkakala Family prayer group was founded by Adi Sutanto. The Immanuel prayer group was held at the Sebadja family residence at Jalan Gajah Mada number 84. The next development was the Immanuel prayer group was affiliated with the synod of the Indonesian Bethel Church (GBI). On April 15, 1989, the Immanuel prayer meeting was changed to GBI Bethany Semarang after Lukas Sebadja was ordained to be a priest of the church by Alex Tanusaputera who was a GBI Bethany Surabaya pastor. Thus, GBI Bethany Semarang becomes a subsidiary of GBI Bethany Surabaya.

In addition to the Immanuel prayer group, the Charismatic prayer group which had a rapid development in the early 1970s was the prayer group of the Sangkakala Family. The Sangkakala Family prayer meeting was pioneered by Adi Sutanto and Yusak Kusama. The Sangkakala family prayer meeting is formed from Farmland Workers Conference Event I (KPLT I) 1967 in Bangsri Jepara. The event was attended by around 200 youths of the Indonesian Muria Christian Church (GKMI) who called themselves Sangkakala youth. In 1970 the activity was stopped due to financial problems, there was no support from GKMI, and the pioneers had to go to college or 
work. The Sangkakala Family prayer group began to reactivate after Adi Sutanto finished his studies in America and settled in Semarang. The activities of charismatic prayer groups can be seen in Figure 1.

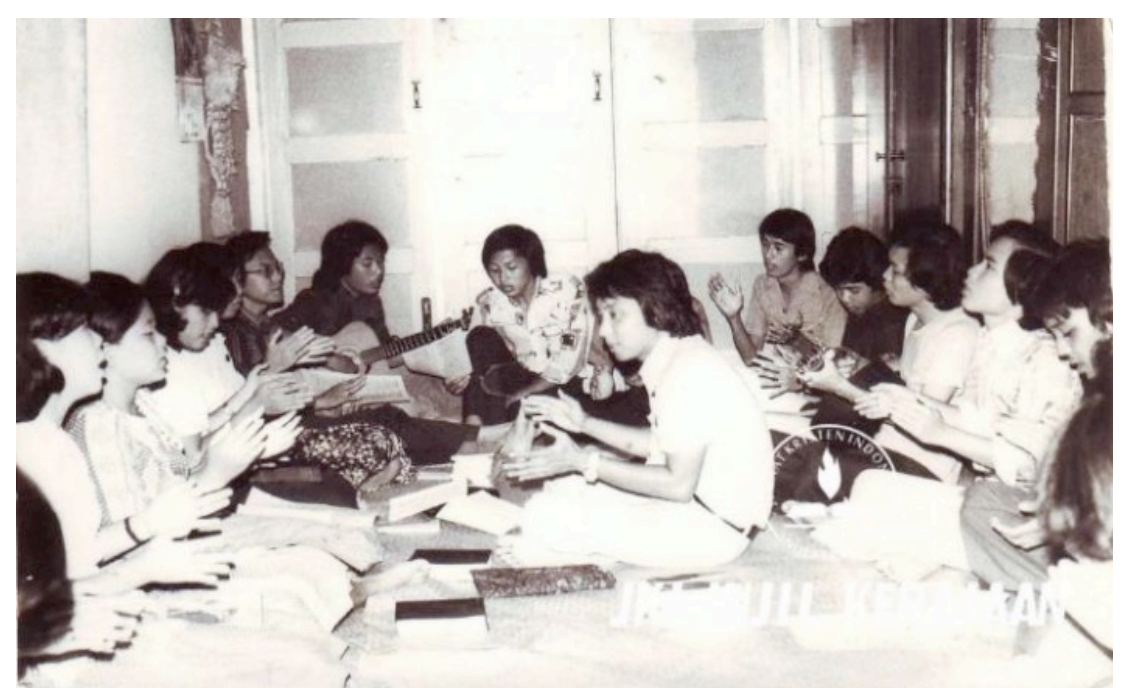

Figure 1. Activities of Kapuran Prayer meeting which is one of the branches of the Sangkakala Family Foundation, 1978.

Adi Sutanto's meeting with Yusak Kusama in 1976 in the city of Semarang led KPLT I alumni to establish a new prayer group, named the Sangkakala Family prayer group. This prayer meeting first held worship in 1976 at Cilosari 666 Semarang, which is the residence of Adi Sutanto. On May 2, 1977 the prayer meeting was registered as a religious organization under the name Tan A Sioue. In 1979, the association was then registered with the Department of Religion of the Central Java Regional Office under the name Sangkakala Family Foundation. In 1983 the foundation was recognized by the Indonesian Ministry of Religion as a foundation for the evangelism of the gospel. In 1985 the foundation developed into a synod under the name of the Indonesian Christian Community (JKI), chaired by Adi Sutanto. The JKI synod member church that was growing rapidly in the city of Semarang was the JKI Royal Gospel founded by Petrus Agung Purnomo on February 20, 1991.

Besides starting from the prayer meeting, the emergence of the Charismatic church in Semarang City also originated from a series of Revival Service (TRC) activities. There are three activities of the TRC which are considered as the momentum of the rise of the Charismatic Church in the city of Semarang. The first TRC took place on March 1-3, 1979 and was attended by around 400 people. The TRC was an early milestone in the rise of charismatic youth in the city of Semarang and bore out several great charismatic church pastors such as Petrus Agung Purnomo and Jimmy Oentoro. The second TRC took place on August 1-3, 1979, which was attended by 2,186 people. The third TRC took place on June 5 -7, 1980 in Mugas field and was attended by around 40,000 people. The TRC was a declaration of the existence of the Charismatic movement in Semarang due to the high enthusiasm of the community for the KKR's activities. 
The series of TRCs was interdenominational so that various church groups were allowed to participate in the activity. The majority of the TRC activities were attended by Christian youth from various regions. the series of TRCs events that took place in the Semarang was an early milestone in the development of the Charismatic movement in various regions in Central Java. The TRC was spearheaded by the Sangkakala Family prayer group and was supported by various Charismatic prayer groups around the city.

\section{Charismatic Church in Semarang, 1985-2015}

The development of the Charismatic church in the city of Semarang as a religious institution began to be seen since 1985, since the issuance of Law number 8 of 1985 which requires religious organizations to be officially registered with the Ministry of Religion. The charismatic church movement is divided into two major groups. The first group is a prayer meeting that combines with the first charismatic church synod, the Indonesian Bethel Church (GBI), while the second group decides to establish a separate synod. One of the charismatic synods of churches that stands in Semarang is the Indonesian Christian Community (JKI). The development of the Charismatic church in Semarang was dominated by two synods, namely the GBI and JKI. The charismatic church that developed rapidly from 1990 to 2015 was GBI Gajah Mada and JKI Gospel Royal.

In the period 1985-2015 the development of the Charismatic church in Semarang City can be divided into two periods, namely the period 1990-2000 and the period 2000-2015. In the first period, the charismatic church that developed rapidly in the city of Semarang was GBI Gajah Mada. It can be seen from the high church development. From 1994-1999 there were more than 1,000 members of the Gajah Mada congregation (GBI Synod, 2019). The Sunday worship activities at the GBI Gajah Mada had to be divided into four sessions. The rapid growth of the number of congregations is partly due to social programs carried out by GBI Gajah Mada under the leadership of Lukas Sebadja, such as health services and prayer visits in hospitals, visits to nursing homes, detention centers, and providing assistance to the poor around the church area. These proved to be able to attract the sympathy of the community so that many Christians in the city of Semarang moved the church to GBI Gajah Mada. The expressive, vibrant, and charismatic style of worship is also a special attraction for Christians in the city of Semarang.

In the second period, the development of the Charismatic church in Semarang was dominated by JKI Injil Kerajaan, led by Petrus Agung Purnomo. JKI of the Kingdom began to develop rapidly since 1999, after the multidimensional crisis in Indonesia. Social service activities in the form of distributing groceries, cheap markets, and spiritual meetings (KKR) in Simpang Lima proved to be effective in attracting congregants. This can be seen from the increase in the number of JKI Injil Kerajaan, which in 1998 only 896 congregations later in 1999 increased to 2,094 congregations. This success has made JKI Injil Kerajaan continue to innovate through the process of deconstruction of evangelistic patterns. 
In 2000 JKI Injil Kerajaan initiated to establish the first Christian spiritual radio station in Central Java (“JKI Injil Kerajaan" n.d.). The idea of Petrus Agung received the support of prominent American evangelist John Avanzini, the support was poured in the form of providing assistance of 50,000 US dollars to support the spiritual radio development activities. On November 242001 the radio was completed and inaugurated with the name Radio Rhema FM. Radio Rhema is a pioneer of Christian spiritual radio in Central Java. Because the number of congregations continues to increase and the number of worship offerings also continues to grow, in $2003 \mathrm{JKI}$ Gospel Royal built a new church with a very large capacity in the Marina Complex area, West Semarang. The new church was completed in 2007 and named the Holy Stadium.

Table 1. Number of JKI Injil Kerajaan Congregation, 1991-2013

\begin{tabular}{cc}
\hline Year & $\begin{array}{c}\text { Number of congregation who } \\
\text { has Congregation Registration } \\
\text { Number }\end{array}$ \\
\hline 1991 & 200 \\
1992 & 400 \\
1993 & 570 \\
1994 & 500 \\
1995 & 550 \\
1996 & 600 \\
1997 & 700 \\
1998 & 896 \\
1999 & 2.094 \\
2000 & 2.670 \\
2001 & 3.557 \\
2002 & 4.007 \\
2007 & 6.762 \\
2009 & 11.630 \\
2013 & 13.324 \\
\hline Source: JKI Injil Kerajaan, 2013.
\end{tabular}

Petrus Agung innovated the pattern of worship by incorporating elements of the Jewish tradition into the worship process. The worshipers used Jewish war robes and symbols used in Jewish traditions such as shofar, menorah, Sharon roses, crowns, star of David, and the ark of the covenant of Moses. JKI Injil Kerajaan also celebrates Jewish holidays such as the commemoration of the Jewish New Year (Rosh Hashanah) and the anniversary of God's peace with the people of Israel (Yom Kippur). The addition of Jewish elements is used to make the atmosphere of worship more solemn. Innovations in worship patterns and social services carried out by JKI Gospel Royal proved to increase the number of congregations. In 2007, when the Holy Stadium was completed, the number of JKI Injil Kerajaan members had increased to 6,762 people. 
Entering 2009 the number of JKI royal congregations reached 11,630 people. The complete development of the number of GKI congregations in the Gospel of the kingdom can be seen in Table 1.

The development of the Charismatic church until 2015 was still dominated by JKI Injil Kerajaan. This can be seen from the JKI Church Gospel congregation data which continues to increase until it reaches 13,324 people. However, the development of the number of congregations is not too significant when compared to previous years. This was allegedly because other churches in the JKI Injil Kerajaan work area began to make efforts to improve congregational recruitment, among others by modernizing patterns of worship as did the JKI Injil Kerajaan. For the charismatic church in 2010 to 2015 it can be said to be an uncertain period because of the emergence of the tradition of the congregation of the streets, namely the congregation who came to a church just to enjoy the atmosphere of worship but did not intend to become the church's congregation. In addition, non-Charismatic churches also began to improve themselves so that the movement of congregations that occurred in the previous period can be minimized.

\section{Charismatic Church and the Christians Religious Life in Semarang}

The massive development of Charismatic church in the last three decades has led to pros and cons in the Christian community and religious leaders. The pros and cons are mainly from churches that have different sects and churches that feel disadvantaged by the evangelistic activities carried out by the Charismatic Church. This can be seen from the statement of Hans Maris, a pastor from the mainstream church. ${ }^{2} \mathrm{He}$ doubts the truth of the language of the Spirit spoken by the Charismatics because it is not certain that the gift comes from God. Hans Maris also doubted the attitude of the Charismatic church that did not criticize the revelations and prophecies delivered by the Charismatic church leaders claimed to come from the Holy Spirit, even though in reality many prophecies and revelations were not Biblical (Maris, 204, pp. 34-36). This is one of the problems that sparked debate between Charismatics and nonCharismatics. This debate certainly affects the harmony between Christians because of the pros and cons of the teachings of the Charismatic church.

The influence of the development of the Charismatic church on antimainstream non-Charismatic churches are seen in the theology of prosperity and offerings by non-Charismatic mainstream churches outside ${ }^{3}$ Pentecostal Churches initially did not prioritize or even rejected theology of prosperity views. ${ }^{3}$ The rapid

2 Mainstream churches hold closely the spirit of reform initiated by Martin Luther. Mainline churches have liturgical grounds and religious ceremonies (sacraments) that can not be changed. Meanwhile, the antimainstream church does not hold tightly to the spirit of church reform, and does a lot of liturgical and sacrament changes. The Charismatic Church belongs to the antimainstream church group.

${ }^{3}$ Theology of prosperity is the view that humans live on earth as in heaven, so that everything in heaven also exists on earth. Manifestation of life in heaven in the form of abundant wealth, health and free from all problems of life as it should be in heaven. 
development of the Charismatic church in the city of Semarang, especially JKI the Injil Kerajaan over the past three decades had sufficiently proven how prosperity theology is in great demand by Christians in the city of Semarang. This made Pentecostal churches, like the Church of Jesus Christ (GIA) Pringgading begins to be pragmatic. GIA Pringgading did a lot of introducing the law of sowing when the church will make offerings (Hendropuspito, 1983). It was also happened to other Pentecostal churches such as the Pentecostal Church in Indonesia (GPdI) and Mawar Sharon Church (GMS).

Since the 2000s GIA Pringgading began to follow Peter Agung steps to develop the teachings of prosperity theology. This was done so that the congregation remained in the GIA Pringgading church, considering that many GIA congregations had moved to the Charismatic church, one of which was due to the theology of prosperity (Suparta, 2019). The efforts can be seen from the themes of the event at GIA Pringgading, such as when the commemoration of Thanks Giving day with the theme "Victims of Thanksgiving Habakkuk" on December 5, 2010 (Pelita Kasih, 2011, p. 23). In addition, the Pelita Kasih published by GIA Pringgading also reveals the prayer of Jabez. Jabez's prayer is the prayer of the prophet Jabez so his life is abundantly blessed, his territory expanded and kept away from all calamity. Jabez Prayer is a prayer that is often chanted by the Charismatic church that embraces theology of prosperity. GIA Pringgading began to realize a shift in Christian views about wealth. Christians start to see that wealth is not a mistake, rather wealth is good for helping others as long as it is obtained in the right way and based on the Bible (Rodemeir, 2016).

In addition, GIA Pringgading since 2005 has also opened several business entities that aim to establish churches and congregations, such as the cooperative "Manna Sejahtera" which is a board formed for the welfare of the people. In addition, GIA Pringgading also established a radio station called Agape FM in 2007 (KPID Central Java, 2018). Radio Agape FM is one of the radios established by the church in Central Java after the founding of Rhema FM Radio belonging to the JKI Injil Kerajaan church. The establishment of cooperatives and radio is a form of church awareness to be more independent and not only rely on offerings from the congregation.

Changes in views did not only occur at GIA Pringgading, but also happened to churches from other denominations around anti-mainstream church (Utomo, 2019). The non-Charismatic anti-mainstream church thought that it was done to survive the influence of the Charismatic church, but actually the effort made to survive was proof that the anti-mainstream church has been influenced by the teachings of the Charismatic church. GIA Pringgading also seeks to make the church economically independent by providing entrepreneurship training, one of them is making salted eggs training to the North Semarang area people.

\section{The relationship among the charismatic church and other churches in Semarang}

Innovations made by the Charismatic Church in interdenominational worship and evangelism patterns had a profound influence on the relationship of the Charismatic Church to other churches. The rapid development of the Charismatic church that was able to attract congregants to thousands of people made many other churches did 
introspection while at the same time looking down on the Charismatic church activities. This is because the non-Charismatic churches had lost many congregations.

From the results of the study noted that the reduced congregation of nonCharismatic churches is mainly due to their interest in worship and evangelism patterns of the Charismatic churches that are adapted to the up to date development towars congregation's conditions, especially young people. The Charismatic Church conducts worship in a more expressive way. Worship activities in the Charismatic church have their own uniqueness. For example, JKI Injil Kerajaan includes elements of Jewish tradition and worship takes place in wisdom and romance while GBI Gajah Mada offers more relaxed and casual worship. The songs sung at the Charismatic church are also more dynamic and there are many new songs that are interesting to the congregation. The Charismatic Church also re-arranges old songs so that they are fresher and more modern in accordance with the tastes of today's congregations. In addition to the charismatic church worship, it also offers a more interesting and effective evangelistic process that is through social services, the social service activities that many charismatic churches do and attract congregations are Revival Service (TCR) activities and cheap market events.

As explained in the section on the development of the Charismatic church, from 1999 to 2013 the number of JKI members of the Injil Kerajaan continued to increase significantly. The increase in congregations turned out to raise suspicion pastors from other churches because some congregations no longer worship in their church. The Charismatic Church is suspected of having taken part of the congregation from other churches, resulting in a negative stigma against the Charismatic Church. The Charismatic Church has been called the "sheep stealer" church. "Sheep stealer" is a term for a church that is considered to steal a church's congregations from another church. Actually, it happened because the congregation did not notify the origin church about their move to another church.

Since the beginning of the Charismatic prayer group was formed, some of the congregations that followed the prayer meeting were indeed from other churches. Members of the Charismatic prayer group come from various denominations. For example, Lukas Sebadja was originally an activist of GKI Karangsaru and Adi Sutanto was an activist of the Indonesian Muria Christian Church (GKMI). The founders of the Charismatic prayer group then invited their fellow activists to join the Charismatic prayer group.

This condition continued until the prayer meeting became a new church and congregations from other churches left their original church to join the Charismatic church. For example, in 1972 the emergence of the Immanuel prayer group had influenced the number of church members from the founders, the GIA synod. The emergence of the prayer meeting resulted in the reduction of the congregation in the GIA Dokter Cipto. The development of church attendance can be seen in Table 2. 
Table 2. The Number of GIA Dokter Cipto Congregation Attendance, 2005-2019

\begin{tabular}{cc}
\hline Year & $\begin{array}{c}\text { Average Congregation } \\
\text { Attendance Number }\end{array}$ \\
\hline 2005 & 1.378 \\
2006 & 1.363 \\
2007 & 1.352 \\
2008 & 1.348 \\
2009 & 1.340 \\
2010 & 1.326 \\
2011 & 1.288 \\
2012 & 1.256 \\
2013 & 1.230 \\
2014 & 1.209 \\
2015 & 1.205 \\
\hline
\end{tabular}

Source: GIA Dokter Cipto.

From the data in Table 2 it can be seen that from 2005 to 2015 there was a decline in church attendance. The data above shows that in 2005 the number of church attendance at GIA Doctor Cipto was 1,378 people, while in 2015 the attendance rate fell to 1,205 people. Meanwhile, in the same year the number of Charismatic church members, such as JKI Injil Kerajaan increased from 11,630 people in 2009 to 13,324 people in 2013. Based on these data it can be assumed that some of the congregations of the GIA Doctor Cipto moved to the Charismatic church. However, these congregations were still members of the GIA Doctor Cipto congregation. When the Charismatic church began losing prestige in early 2016 because of the death of the priest Peter Agung Purnomo, many of these congregations returned to their original church.

The charismatic church activity not only affects the anti-mainstream church congregation, but also affects the number of mainstream church congregations. One of the main church synods affected by the activities of the Charismatic church in the city of Semarang was the Javanese Christian Church (GKJ). According to Yahya Tirta (2020), the activities of the Charismatic church attracted a lot of young church members of the GKJ because the charismatic church worship was more expressive, some young people joined the charismatic church worship but there were also congregations that were still registered as members of the GKJ congregation.

The number of GKJ congregations in Semarang from 2003 to 2006 was decrease. It is caused the GKJ to add an area that was originally only two classes, namely South and East Semarang and developed into three classrooms with the addition of the new West Semarang class. Class is the unity of the church area under the auspices of the synod. The addition of classicism carried out by the GKJ synod aims to make the services of the congregation more optimal considering charismatic church movement in those years was very massive with methods of social service to the villages. One of the coverage areas of the West Semarang cluster is the North Semarang area which 
was the JKI Injil Kerajaan evangelistic mission area. Besides, the addition of the cluster also aims to stem the influence of the Charismatic church in the area of North Semarang and West Semarang. The effort was carried out by transforming itself into a missionary church through more active deaconess (social service) activities. Its primary activity was to provide scholarship compensation from elementary to high school level. GKJ is also developing a Santosa school, a free school for underprivileged children managed by the Urbanist Commission in the Bandarjo Village (Tanjung Emas Port).

\section{Table 3. The Relation between Charismatic Church and Mainstream Church}

\begin{tabular}{|c|c|c|}
\hline Synod & Relationship with Charismatic Church & Ecumenical Institutional Relations \\
\hline GKJ & $\begin{array}{l}\text { Difference theology caused the difficulty } \\
\text { in working together directly, except } \\
\text { through PGI. Relationship is limited to } \\
\text { being active in the local Inter-Church } \\
\text { Cooperation Agency (BKSAG). }\end{array}$ & $\begin{array}{l}\text { Members and founders of PGI, PGI } \\
\text { Regional Cooperation with GKI (SW } \\
\text { Central Java): LPPS, Health Services } \\
\text { (Yakkum), Scholarship Commission, and } \\
\text { Education Foundation (YPK). }\end{array}$ \\
\hline GIA & $\begin{array}{l}\text { Relationships are quite good although } \\
\text { there is a filtering on the inclusion of } \\
\text { charismatic movements. }\end{array}$ & GIA members of PGI, PGIW and CCA \\
\hline GKI & $\begin{array}{l}\text { Begins adapting the Charismatic liturgy } \\
\text { through the Faith Refreshment Service } \\
\text { and the organization of the TRC }\end{array}$ & $\begin{array}{l}\text { The members and founders of PGI and } \\
\text { PGIW. }\end{array}$ \\
\hline GKP & $\begin{array}{l}\text { Begins to adapt the Charismatic liturgy } \\
\text { through Faith Refreshment Service. }\end{array}$ & $\begin{array}{l}\text { Members and founder of PGI, PGIW. } \\
\text { Involved with church organizations at the } \\
\text { national and regional level. }\end{array}$ \\
\hline GPIB & $\begin{array}{l}\text { Difference theology caused hard to work } \\
\text { together, except through PGI. }\end{array}$ & $\begin{array}{l}\text { The members and founder of PGI, PGIW } \\
\text { collaborated with other equal churches. } \\
\text { Joining BKSAG tendency because of } \\
\text { political reasons }\end{array}$ \\
\hline
\end{tabular}

Source: Litkom-PGI Research Team, 2010.

The Charismatic church generally was congregation from another church and was still registered in the original church. The lack of an orderly administration of the church congregation coupled with the weak communication between pastors in the city of Semarang made the membership status of the congregation ambiguous, so that there were many misunderstandings between pastors from one church and pastors from other churches, especially pastors who felt disadvantaged because the congregation had moved to many Charismatic churches. This condition was worsened by the lack of awareness of the congregation to orderly by removing the membership of the congregation from the previous church. It seems that the congregation is reluctant to give up membership in the original church because the family system in the mainstream church is so strong that if there is marriage or death, many congregations have moved to the Charismatic church and then returned to the original church. These various conditions have caused a rift in relations among churches in 
Semarang. The relationship between the Charismatic church and the mainstream church can be seen in Table 3 .

From Table 3 it can be seen that the majority of mainstream churches reject the presence of the Charismatic church. Criticism and rejection as shown in table 4 are conveyed normatively, but implicitly the statement "theological difference" is a form of rejection and incompatibility of the majority of mainstream churches against the Charismatic church. Table 3 also shows that some mainstream churches have begun to adapt the patterns of worship and evangelism conducted by the Charismatic Church. Activities that have been adapted by many mainstream churches are refreshing the faith through the Revival Service (TRC) and strengthening social services to the community so that it becomes missionary church.

The Communion of Churches in Indonesia (PGI) which has existed since 1950, actually makes the relationship between the synods of churches in Indonesia more active in communication. But along with the emergence of the Charismatic church, not all PGI members want to accept the Charismatic church as a member of PGI. The rejection can be seen from the attitudes of other churches towards the GBI synod, the first charismatic church that became a member of PGI in 1990 (SK PGI No. 11 / PGI-XI / SKET / 1990). GBI became the 61st member while JKI became the 89th PGI member in 2014 through the PGI Complete Workers' Assembly (MPL) session in Nias, North Sumatra. Although there are some PGI members who disagree with the existence of the Charismatic church in PGI, the inclusion of the two Charismatic synods indicates that the Charismatic church is actually also beginning to be accepted and recognized by the mainstream churches.

The merging of Charismatic churches into the PGI facilitates supervision of the activities of the Charismatic church and expedites communication with the church, bearing in mind that the Charismatic church's mission program is to win new souls; and many new souls won also came from other churches. The existence of PGI is expected to be able to maintain communication and harmony of the church in Indonesia from various denominations.

Besides PGI, there are other institutions in charge of resolving disputes between priests. The institution formed by the priests is the Inter-Church Consultative Board (BAMAG) which is a forum for pastors to establish communication. In Semarang BAMAG was officially established in 2005. The presence of BAMAG is enough to help strengthening the communication network among pastors so that every problem can be resolved through mediation before it spreads to the people. According to Bambang Mulyanto (2019), One of the problems that was successfully resolved by BAMAG was the conflict that occurred among Pastor Petrus Agung and several nearby churches at the beginning of the Holy Stadium establishment. The surrounding churches feel disturbed by the social service activities carried out by JKI Injil Kerajaan that caused some of their congregations to disappear. The churches were indicated to have joined the JKI Injil Kerajaan. The conflict could be resolved by mediating and asking the congregation concerned to choose one church membership. BAMAG also seeks to strengthen communication between priests in Semarang by holding holiday 
celebrations together such as Christmas and Easter across the city. BAMAG Semarang also integrates with government agencies such as the Kesbangpolimas, the Semarang Christian Community Guidelines, and the Central Java Christian Community Guidelines. Integration between agencies is done to minimize conflicts in the religious life of Christians in Semarang.

\section{Conclusion}

The emergence and development of the Charismatic church in Semarang brought a new wind in the pattern of Christian worship. The pattern of worship which is expressive, up to date and social activities that touch the wider community, especially the lower classes, has changed the religious life of Christians. However, the positive development of charismatic churches poses problems for non-charismatic churches because some congregations leave their churches to join the charismatic churches. Friction between the priests had happened because of suspicion of the Charismatic church. The dynamics in the religious life of Christians in the city of Semarang is a history fragment which can certainly be a lesson in religious life and harmonious relations between religious people.

\section{References}

Aritonang, J. S. (2005). Berbagai aliran di dalam dan di sekitar gereja. Jakarta: BPK Gunung Mulia.

Basri, S. (2016). Strategi Misi Gereja JKI Injil Kerajaan Holy Stadium-Semarang (Master thesis). Sekolah Tinggi Theologia Abdiel, Semarang.

BPS Semarang. (2010). Data hasil sensus penduduk kota Semarang berdasarkan agama tahun 1990-2010. Biro Pusat Statistik Kota Semarang.

Gottschalk, L. 1983. Mengerti sejarah, translated by Nugroho Notosusanto. Jakarta: Universitas Indonesia Press.

Hendropuspito (1983). Sosiologi agama. Yogyakarta: Kanisius.

JKI Injil Kerajaan. Sejarah dan pendiri JKI Injil Kerajaan. Retrieved from http://newchapter.jkiinjilkerajaan.org.

JKI Sinode (2013). Direktori Sinode jemaat Kristen Indonesia tahun 2013. Salatiga: Sinode JKI.

Kartodirdjo, S. (1993). Pendekatan ilmu sosial dalam metodologi sejarah. Jakarta: Gramedia Pustaka Utama.

Litkom-PGI Research Team (2010). Inter-Church Self-portrait Comparison: Challenges and Responses. Jakarta: PGI Research and Communication Bureau.

Maris, H. (2014). Gerakan kharismatik dan gereja kita. Surabaya: Momentum press.

Notosusanto, N. (1984) Hakekat sejarah dan metode sejarah. Jakarta: Mega Book Store. Rodemeier, S. (2016). Kajian atas Gereja Pentakosta-Kharismatik di Jawa, Indonesia. Gema Theologika (1): 31-54. https://doi.org/10.21460/gema.2016.11.210

Rodemeier, S. (2017). Emergence and establishment of a charismatic church within the framework of Javanese self-perception in Surakarta, Indonesia. Indonesia and the Malay World, 45 (131): 66-87. https://doi.org/10.1080/13639811.2017.1268447 
Suparta, H. (2009). Mengenal pentakostalisme di Indonesia. Jurnal Abdiel, 3(2): 11-24. https://doi.org/10.37368/ja.v3i2.97

Sutanto, A. (1986). A strategy for planting churches in Java through the Sangkakala mission with special emphasis on the Javanese and Chinese people (Doctoral dissertation). The School of World Mission And Institute of Church Growth Fuller Theological Seminary.

Sutoyo, D. (2018). Analisis Historis terhadap Teologi Gerakan Pentakostalisme. Dunamis: Jurnal Teologi dan Pendidikan Kristen, 2 (2): 167-196.

https://doi.org/10.30648/dun.v2i2.171

Tim GBI Gajah Mada (2014) Direktori 25 tahun GBI Gajah Mada Semarang, Sejarah berdirinya gereja. Semarang: GBI Gama.

van Kooij, R. Tsalatsa, Y. (2007) Bermain dengan Api, Relasi antara Gereja-gereja Mainstream dan kalangan Kharismatik Pentakosta Jakarta: BPK Gunung Mulia.

Wiraatmaja, S. (2015) Study on the growth of three JKI Churches in Ungaran, Kudus and Semarang on 1982-2002 (Master thesis). Seminari Theologi Baptis Indonesia (STBI) Semarang. 